\title{
Synchronised sartorius avulsions in adolescent sprinter
}

\author{
Christopher James Manning, ${ }^{1}$ Sharad Singhai, ${ }^{2}$ Paul Marshall ${ }^{2}$
}

'Stepping Hill Hospital, Stockport, Stockport, UK ${ }^{2}$ Royal Lancaster Infirmary, Lancaster, Lancashire, UK

\section{Correspondence to}

Christopher James Manning, cmanning2@doctors.org.uk

Accepted 27 June 2016

\section{CrossMark}

To cite: Manning CJ, Singhai S, Marshall P. BMJ Case Rep Published online: [please include Day Month Year] doi:10.1136/bcr-2016216739

\section{DESCRIPTION}

Apophyseal avulsions occur with a sudden forceful contraction at an unfused apophysis. Radiographic signs of apophyseal avulsions of the hip and pelvis are often subtle. When suspicion of these injuries is high, a thorough knowledge of tendon attachments around this area can allow particular review of these areas when assessing the patient and subsequent radiographs.

We met a 15 -year-old boy who was referred to orthopaedics with severe bilateral hip pain. He had been running in the $100 \mathrm{~m}$ sprint at the school sports day. He felt a sudden 'pop' at both his hips while sprinting and was unable to continue. He was able to walk off the track but reported of severe pain in the right and left hip region.

On examination he was tender over the right and left anterior superior iliac spine (ASIS) and had painful active hip flexion bilaterally. X-rays showed avulsions at the apophysis of the right and left anterior inferior iliac spine (figure 1). $\mathrm{He}$ was managed conservatively with regular clinical review, analgesia and protected weight bearing with crutches.

At 2 weeks the pain was improving, he had mild tenderness over the right and left ASIS, the active straight legs were raised to $90^{\circ}$ without much pain. At 6 weeks he was walking normally and X-rays showed that there was ossification around the upper epiphysis, bilaterally. This bilateral injury is rare with few case reports published, however, each has an identical mechanism. ${ }^{1}{ }^{2}$

Apophyseal avulsion fractures can be subtle; however, knowledge of tendon attachments can focus clinical and radiographic review (figure 2).

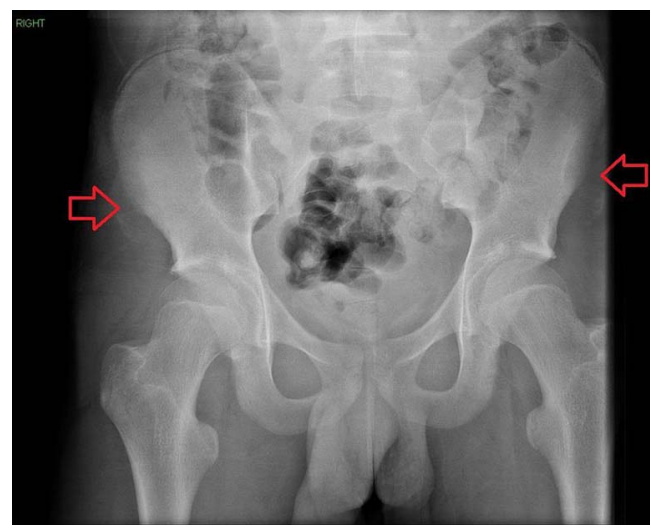

Figure $1 \mathrm{X}$-ray on initial presentation to the emergency department. Arrows showing bilateral avulsion of anterior superior iliac spine at the origin of sartorius attachment to the pelvis.

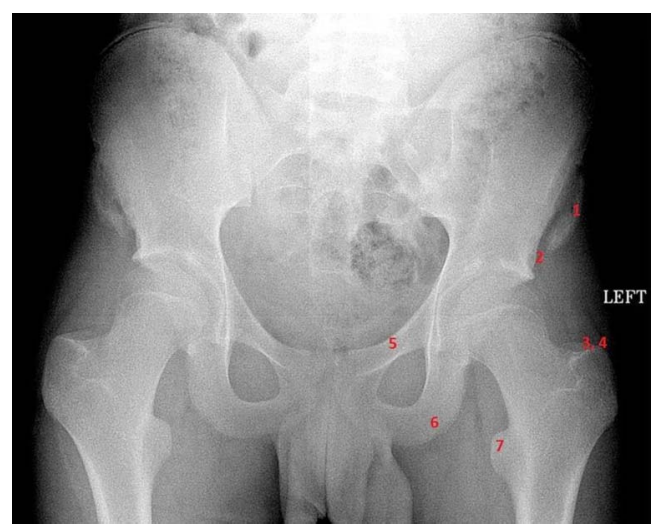

Figure 2 X-ray at 6 weeks postinjury showing evidence of ossification. Major tendinous insertions have been labelled on the X-ray and summarised below (3).

\begin{tabular}{lll}
\hline 1. & Sartorius & Anterior superior iliac spine \\
2. & Rectus femoris & Anterior inferior iliac spine \\
3. Gluteus medius & Greater trochanter of femur \\
4. Gluteus minimus & Greater trochanter of femur \\
5. Hip adductors & Pubis \\
6. Hamstrings & Ischial tuberosity \\
7. lliopsoas & Lesser trochanter of femur
\end{tabular}

\section{Learning points}

Apophyseal avulsion fractures can be subtleknowledge of tendon attachments can focus clinical and radiographic review.

- Review of major tendinous attachments around hip and pelvis.

- Avulsion injuries can be bilateral, and sprinting is common mechanism of injury.

Contributors CJM and SS performed literature search, drafted figures and manuscript. PM helped plan and provided review and editing of the final manuscript. The patient's care was undertaken by SS and PM.

Competing interests None declared.

Patient consent Obtained.

Provenance and peer review Not commissioned; externally pee reviewed.

\section{REFERENCES}

1 Khoury MB, Kirks DR, Martinez $S$, et al. Bilateral avulsion fractures of the anterior superior iliac spines in sprinters. Skeletal Radiol 1985;13:65-7.

2 Boyce SH, Quigley MA. Simultaneous bilateral avulsion fractures of the anterior superior iliac spines in an adolescent sprinter. BMJ Case Reports 2009;2009:bcr05.2009.1827. 


\section{Images in...}

Copyright 2016 BMJ Publishing Group. All rights reserved. For permission to reuse any of this content visit http://group.bmj.com/group/rights-licensing/permissions.

BMJ Case Report Fellows may re-use this article for personal use and teaching without any further permission.

Become a Fellow of BMJ Case Reports today and you can:

- Submit as many cases as you like

- Enjoy fast sympathetic peer review and rapid publication of accepted articles

- Access all the published articles

- Re-use any of the published material for personal use and teaching without further permission

For information on Institutional Fellowships contact consortiasales@bmjgroup.com

Visit casereports.bmj.com for more articles like this and to become a Fellow 